Editorial

\title{
Science, Innovation and Education as Pillars of High-Quality Implant Dentistry: Overcoming Challenges through Innovation Dictates Trends
}

\author{
Miguel de Araújo Nobre ${ }^{1,2}$ (1) \\ 1 University Clinic of Stomatology, Faculty of Medicine, University of Lisbon, 1649-028 Lisbon, Portugal; \\ mnobre@maloclinics.com \\ 2 Research and Development Department, Maló Clinic, 1600-042 Lisbon, Portugal
}

Received: 18 May 2020; Accepted: 19 May 2020; Published: 22 May 2020

The evolution of implant dentistry since the discovery of the osseointegration concept has been remarkable. I was lucky enough to experience firsthand the early developments and later massification of the immediate loading and immediate function protocols through the All-on- $4{ }^{\circledR}$ concept, since 1999, when Professor Paulo Maló informed me that after having consulted with Professor Bo Rangert, both agreed that a young clinician (me) should work on the study. Later in 2003, that young clinician was included as one of the three original co-authors in the first All-on- $4{ }^{\circledR}$ concept manuscript [1]. I am very grateful to both these Professors for providing such opportunity and for mentoring me throughout the years. The development of immediate function protocols, at that time an innovation, was not an easy task, considering the resistance to change that usually accompanies any novelty. In this situation, the resistance to change was only broken through science, education, and a high dose of resilience from a hand-full of clinician-researchers, elevating immediate function and immediate loading protocols to the standard of care today.

Now, as then, it is the challenge of treating patients that drives innovation and dictates trends, always with high quality care as goal. The present Special Issue, "Implant Dentistry-Trends, Challenges and Innovations", was assembled as a catalyst for innovation and a forum for presenting and discussing the treatment of challenging situations. Innovation and validation of concepts are displayed in this Special Issue, at different levels. Starting with immediate loading, a systematic review comprised of 34 prospective studies published in this Special Issue, estimated a mean weighted implant survival of $97.4 \%$, together with stable peri-implant bone level changes, leading the authors to conclude that, under defined circumstances, it appears to have long-term predictability and a good success rate [2].

Currently, several concepts are being developed to increase the predictability of the rehabilitation, while aiming to reduce treatment time. One of the areas developed concerns the digital workflow [3], with much margin for improvement in the immediate future, either through an improved dental clinic-dental laboratory communication [4], or the potential application of customized prefabricated immediate provisional restorations [5]. According to a randomized controlled trial, no significant differences were registered in the success rate and marginal bone level between the immediate loading of dental implants employed from the digital workflow and the conventional implant treatment technique [6]. Still, considering the digital aspect of implant dentistry, computer-aided dynamic navigation for implant placement has emerged in recent years, allowing accurate implant placement and being considered as a safe and predictable procedure $[7,8]$.

Implant dentistry was built on the challenges posed by the need to satisfactorily restore the patients' dentition, with science standing as cornerstone. Evidence-based decisions should stand as foundations for the ultimate goal of providing high quality care to all $[9,10]$. This allowed developing protocols to successfully rehabilitate patients with challenging conditions, including patients with 
Hypodontia [11], or using zygomatic anchored implants as a successful alternative option for graftless restoration of the severely resorbed maxilla, including immediate loading protocols [12]. Moreover, innovation might be the response to overcome challenges that demand a skillful solution as registered in a retrospective study, where the use of a low-resorption collagen membrane coverage produced comparable results to suturing when attempting to seal ruptured Schneiderian membranes [13].

Innovation in implant dentistry includes methods, comprising both surgical [14] and prosthetic preparation techniques [15,16], post-operative interventions to increase implant stability [17], or new methods of measuring peri-implant bone [18], aiming to increase the probability of success in the long term. Innovation in implant dentistry also includes new materials and surface treatments. One such material is Polyetheretherketone (PEEK), considered a prime candidate to replace metallic implants and prostheses in orthopedic, spine and cranio-maxillofacial surgeries [19]. Additionally, substantial research efforts are undertaken in the development of bioactive implant surfaces, combining antimicrobial activity with osteogenic capacity to achieve correct osseointegration and long-term stability $[20,21]$. Innovation in implant dentistry is paramount, but only when the benefits are incremental or exponential when compared to the state-of-the-art. This makes it mandatory to perform comparisons between techniques in order to validate new methods, to otherwise account for reproducibility of current methods if no incremental gain is registered [22,23], or to evaluate the impact of previous methods in the long-term [24]. In any of the three scenarios, science emerges victorious.

The connection of a final implant-supported fixed prosthesis allowing high satisfaction of both patient and clinician stands as a landmark for success. However, it does not guarantee the maintenance of success in the long term. Peri-implant pathology (otherwise known as peri-implantitis, including all the anecdotal connections to imply a disease process similar to periodontitis-which is not!) $[25,26]$ is regarded as the primary process for late implant failure. Therefore, it is important to develop tools that provide risk assessment based on science and data (rather than opinions), to enable both clinicians and patients to produce the necessary changes that increase the probability of success. The risk assessment tool for peri-implant pathology published in this Special Issue is the first in implant dentistry to be validated, registering an excellent discriminating capacity for indicating which patients were at greater risk during a five-year post-surgery follow-up period [27]. Moreover, this risk assessment tool was made open access through the Foundation for Oral Rehabilitation (https://www.for.org/en/treat/peri-implant-pathology-risk-assessment/take). Even when delivering high quality restorations and attempting to control potential risk factors, peri-implant pathology can occur. This poses a significant challenge for the recovery of the peri-implant complex, due to both the doubts concerning current treatments [28] and the early stage of the development of new treatments [29]. The first prognostic model for implants with peri-implant disease to be derived and validated in implant dentistry was published in this Special Issue, being useful to understand the prognosis of the implant(s) in question and shed light on the possible (favorable or unfavorable) outcomes [30].

Finally, there is education, whose absence would render translational science impossible or meaningless. A narrative review published in this Special Issue discusses the evolution of training and education in implant dentistry. The authors forecast a rapid evolution over the next decade, as technologies already being used in other industries (displayed and discussed in the manuscript) are incorporated into new and innovative learning models [31]. Furthermore, the merging of technological innovations is suggested to culminate in "Digital Dentistry", which in turn will render "Digital Education of Digital Dentistry" inevitable.

It can be interpreted from the present Editorial (written as a summary of the 28 published manuscripts) that the present Special Issue provides an insightful reading to contemporary and future implant dentistry. The complete collection is provided open access for the reader to explore. For this to be possible, we must acknowledge the effort of all authors and reviewers that contributed for this Special Issue, whose commitment is deeply appreciated. Happy reading!

Conflicts of Interest: The author declares no conflicts of interest. 


\section{References}

1. Maló, P.; Rangert, B.; Nobre, M. “All-on-Four" immediate-function concept with Brånemark System implants for completely edentulous mandibles: A retrospective clinical study. Clin. Implant. Dent. Relat. Res. 2003, 5, S2-S9. [CrossRef] [PubMed]

2. Del Fabbro, M.; Testori, T.; Kekovic, V.; Goker, F.; Tumedei, M.; Wang, H.L. A Systematic Review of Survival Rates of Osseointegrated Implants in Fully and Partially Edentulous Patients Following Immediate Loading. J. Clin. Med. 2019, 8, 2142. [CrossRef] [PubMed]

3. Oh, K.C.; Paik, J.; Kim, J.H. Esthetic Rehabilitation of Maxillary Anterior Teeth, Including an Immediate Provisionalization with an Implant-Supported Fixed Dental Prosthesis. J. Clin. Med. 2019, 8, 428. [CrossRef] [PubMed]

4. Cabanes-Gumbau, G.; Soto-Peñaloza, D.; Peñarrocha-Diago, M.; Peñarrocha-Diago, M. Analogical and Digital Workflow in the Design and Preparation of the Emergence Profile of Biologically Oriented Preparation Technique (BOPT) Crowns over Implants in the Working Model. J. Clin. Med. 2019, 8, 1452. [CrossRef]

5. Oh, K.C.; Kim, J.H.; Woo, C.W.; Moon, H.S. Accuracy of Customized Prefabricated Screw-Type Immediate Provisional Restorations after Single-Implant Placement. J. Clin. Med. 2019, 8, 490. [CrossRef]

6. Rattanapanich, P.; Aunmeungtong, W.; Chaijareenont, P.; Khongkhunthian, P. Comparative Study between an Immediate Loading Protocol Using the Digital Workflow and a Conventional Protocol for Dental Implant Treatment: A Randomized Clinical Trial. J. Clin. Med. 2019, 8, 622. [CrossRef]

7. Mediavilla Guzmán, A.; Riad Deglow, E.; Zubizarreta-Macho, Á.; Agustín-Panadero, R.; Hernández Montero, S. Accuracy of Computer-Aided Dynamic Navigation Compared to Computer-Aided Static Navigation for Dental Implant Placement: An In Vitro Study. J. Clin. Med. 2019, 8, 2123. [CrossRef]

8. Lopes, A.; de Araújo Nobre, M.; Santos, D. The Workflow of a New Dynamic Navigation System for the Insertion of Dental Implants in the Rehabilitation of Edentulous Jaws: Report of Two Cases. J. Clin. Med. 2020, 9, 421. [CrossRef]

9. Delgado-Ruiz, R.; Swanson, P.; Romanos, G. Systematic Review of the Long-Term Effects of Transgender Hormone Therapy on Bone Markers and Bone Mineral Density and Their Potential Effects in Implant Therapy. J. Clin. Med. 2019, 8, 784. [CrossRef]

10. Aouini, W.; Lambert, F.; Vrielinck, L.; Vandenberghe, B. Patient Eligibility for Standardized Treatment of the Edentulous Mandible: A Retrospective CBCT-Based Assessment of Mandibular Morphology. J. Clin. Med. 2019, 8, 616. [CrossRef]

11. Attia, S.; Schaaf, H.; El Khassawna, T.; Malhan, D.; Mausbach, K.; Howaldt, H.P.; Streckbein, P. Oral Rehabilitation of Hypodontia Patients Using an Endosseous Dental Implant: Functional and Aesthetic Results. J. Clin. Med. 2019, 8, 1687. [CrossRef] [PubMed]

12. Davó, R.; Bankauskas, S.; Laurincikas, R.; Koçyigit, I.D.; Mate Sanchez de Val, J.E. Clinical Performance of Zygomatic Implants-Retrospective Multicenter Study. J. Clin. Med. 2020, 9, 480. [CrossRef] [PubMed]

13. Barbu, H.M.; Iancu, S.A.; Jarjour Mirea, I.; Mignogna, M.D.; Samet, N.; Calvo-Guirado, J.L. Management of Schneiderian Membrane Perforations during Sinus Augmentation Procedures: A Preliminary Comparison of Two Different Approaches. J. Clin. Med. 2019, 8, 1491. [CrossRef] [PubMed]

14. Velikov, S.; Susin, C.; Heuberger, P.; Irastorza-Landa, A. A New Site Preparation Protocol That Supports Bone Quality Evaluation and Provides Predictable Implant Insertion Torque. J. Clin. Med. 2020, 9, 494. [CrossRef] [PubMed]

15. Agustín-Panadero, R.; Bustamante-Hernández, N.; Solá-Ruíz, M.F.; Zubizarreta-Macho, Á.; Fons-Font, A.; Fernández-Estevan, L. Influence of Biologically Oriented Preparation Technique on Peri-Implant Tissues; Prospective Randomized Clinical Trial with Three-Year Follow-Up. Part I: Hard Tissues. J. Clin. Med. 2019, 8, 2183. [CrossRef]

16. Agustín-Panadero, R.; Bustamante-Hernández, N.; Labaig-Rueda, C.; Fons-Font, A.; Fernández-Estevan, L.; Solá-Ruíz, M.F. Influence of Biologically Oriented Preparation Technique on Peri-Implant Tissues; Prospective Randomized Clinical Trial with Three-Year Follow-Up. Part II: Soft Tissues. J. Clin. Med. 2019, 8, 2223. [CrossRef]

17. Flieger, R.; Gedrange, T.; Grzech-Leśniak, K.; Dominiak, M.; Matys, J. Low-Level Laser Therapy with a 635 nm Diode Laser Affects Orthodontic Mini-Implants Stability: A Randomized Clinical Split-Mouth Trial. J. Clin. Med. 2019, 9, 112. [CrossRef] 
18. Marotti, J.; Neuhaus, S.; Habor, D.; Bohner, L.; Heger, S.; Radermacher, K.; Wolfart, S. High-Frequency Ultrasound for Assessment of Peri-Implant Bone Thickness. J. Clin. Med. 2019, 8, 1539. [CrossRef]

19. Han, X.; Sharma, N.; Xu, Z.; Scheideler, L.; Geis-Gerstorfer, J.; Rupp, F.; Thieringer, F.M.; Spintzyk, S. An In Vitro Study of Osteoblast Response on Fused-Filament Fabrication 3D Printed PEEK for Dental and Cranio-Maxillofacial Implants. J. Clin. Med. 2019, 8, 771. [CrossRef]

20. Asensio, G.; Vázquez-Lasa, B.; Rojo, L. Achievements in the Topographic Design of Commercial Titanium Dental Implants: Towards Anti-Peri-Implantitis Surfaces. J. Clin. Med. 2019, 8, 1982. [CrossRef]

21. Ayukawa, Y.; Oshiro, W.; Atsuta, I.; Furuhashi, A.; Kondo, R.; Jinno, Y.; Koyano, K. Long Term Retention of Gingival Sealing around Titanium Implants with $\mathrm{CaCl}(2)$ Hydrothermal Treatment: A Rodent Study. J. Clin. Med. 2019, 8, 1560. [CrossRef] [PubMed]

22. Attia, S.; Narberhaus, C.; Schaaf, H.; Streckbein, P.; Pons-Kühnemann, J.; Schmitt, C.; Neukam, F.W.; Howaldt, H.P.; Böttger, S. Long-Term Influence of Platelet-Rich Plasma (PRP) on Dental Implants after Maxillary Augmentation: Retrospective Clinical and Radiological Outcomes of a Randomized Controlled Clinical Trial. J. Clin. Med. 2020, 9, 355. [CrossRef] [PubMed]

23. Attia, S.; Narberhaus, C.; Schaaf, H.; Streckbein, P.; Pons-Kühnemann, J.; Schmitt, C.; Neukam, F.W.; Howaldt, H.P.; Böttger, S. Long-Term Influence of Platelet-Rich Plasma (PRP) on Dental Implants after Maxillary Augmentation: Implant Survival and Success Rates. J. Clin. Med. 2020, 9, 391. [CrossRef] [PubMed]

24. Merino, J.J.; Cabaña-Muñoz, M.E.; Toledano Gasca, A.; Garcimartín, A.; Benedí, J.; Camacho-Alonso, F.; Parmigiani-Izquierdo, J.M. Elevated Systemic L-Kynurenine/L-Tryptophan Ratio and Increased IL-1 Beta and Chemokine (CX3CL1, MCP-1) Proinflammatory Mediators in Patients with Long-Term Titanium Dental Implants. J. Clin. Med. 2019, 8, 1368. [CrossRef] [PubMed]

25. Zarb, G.; Koka, S.; Albrektsson, T. Hyperbole, clinical dissonance, and scratching the surface: Complication or disease? Int. J. Prosthodont. 2013, 26, 311. [PubMed]

26. De Araújo Nobre, M.; Mano Azul, A.; Rocha, E.; Maló, P. Risk factors of peri-implant pathology. Eur. J. Oral Sci. 2015, 123, 131-139. [CrossRef]

27. De Araújo Nobre, M.; Salvado, F.; Nogueira, P.; Rocha, E.; Ilg, P.; Maló, P. A Peri-Implant Disease Risk Score for Patients with Dental Implants: Validation and the Influence of the Interval between Maintenance Appointments. J. Clin. Med. 2019, 8, 252. [CrossRef]

28. Toma, S.; Brecx, M.C.; Lasserre, J.F. Clinical Evaluation of Three Surgical Modalities in the Treatment of Peri-Implantitis: A Randomized Controlled Clinical Trial. J. Clin. Med. 2019, 8, 966. [CrossRef]

29. Koch, M.; Göltz, M.; Xiangjun, M.; Karl, M.; Rosiwal, S.; Burkovski, A. Electrochemical Disinfection of Dental Implants Experimentally Contaminated with Microorganisms as a Model for Periimplantitis. J. Clin. Med. 2020, 9, 475. [CrossRef]

30. Nobre, M.A.; Salvado, F.; Nogueira, P.; Rocha, E.; Ilg, P.; Maló, P. A Prognostic Model for the Outcome of Nobel Biocare Dental Implants with Peri-Implant Disease after One Year. J. Clin. Med. 2019, 8, 1352. [CrossRef]

31. Ferro, A.S.; Nicholson, K.; Koka, S. Innovative Trends in Implant Dentistry Training and Education: A Narrative Review. J. Clin. Med. 2019, 8, 1618. [CrossRef] [PubMed]

(C) 2020 by the author. Licensee MDPI, Basel, Switzerland. This article is an open access article distributed under the terms and conditions of the Creative Commons Attribution (CC BY) license (http://creativecommons.org/licenses/by/4.0/). 